\title{
Variations in the equilibrium line altitude of Urumqi Glacier No.1, Tianshan Mountains, over the past 50 years
}

\author{
DONG ZhiWen*, QIN DaHe, REN JiaWen, LI KaiMing \& LI ZhongQin
}

State Key Laboratory of Cryospheric Sciences, Cold and Arid Regions Environmental and Engineering Research Institute, Chinese Academy of Sciences, Lanzhou 730000, China

Received April 20, 2012; accepted September 12, 2012; published online November 10, 2012

\begin{abstract}
The glacier ELA is one of the important parameters reflecting climate change. Based on observations of the equilibrium line altitude (ELA) of Urumqi Glacier No.1 in the Tianshan Mountains, we established a statistical model between ELA and its major influencing factors, warm season air temperature (air temperature averages for May, June, July and August) and annual precipitation. Result showed that, warm season air temperature was the leading climatic factor influencing ELA variations. The glacier ELA ascends (descends) $61.7 \mathrm{~m}$ when warm season air temperature increases (decreases) by $1^{\circ} \mathrm{C}$, and ascends (descends) $13.1 \mathrm{~m}$ when cold season precipitation decreases (increases) by 10\%. In the period 1959-2008, the glacier ELA showed a general increasing trend, ascending $108 \mathrm{~m}$ and reaching its highest altitude in 2008 at $4168 \mathrm{~m}$ a.s.l., close to the glacier summit. If future climate is similar to that in the past 50 years, the ELA of Urumqi Glacier No.1 will still ascend with a speed of $2.16 \mathrm{~m} / \mathrm{a}$. However, If future climate is similar to that in the period 2000-2008, the ELA will still ascend with a speed of $6.5 \mathrm{~m} / \mathrm{a}$ before it is stable. As a result of ELA variation, the accumulation area ratio (AAR) of the glacier showed a decreasing trend during the past 50 years.
\end{abstract}

Tianshan Mountains, Urumqi Glacier No.1, ELA, global warming

Citation: Dong Z W, Qin D H, Ren J W, et al. Variations in the equilibrium line altitude of Urumqi Glacier No.1, Tianshan Mountains, over the past 50 years. Chin Sci Bull, 2012, 57: 4776-4783, doi: 10.1007/s11434-012-5524-1

As global warming in the 20th century, mountain glaciers become very sensitive to climate change. Glaciers all over the world showed an accelerated melting trend during recent 30 years [1]. In western China, glaciers also showed strong retreating, and the ELA of glaciers showed an increasing trend during the past 50 years [2,3]. The equilibrium line altitude (ELA) is a theoretical line on a glacier at which annual mass accumulation equals annual mass loss [3]. Glacier behaviors such as advancing or retreating are controlled by the variations in ELA. Relative to its steady state, a glacier advances when its ELA falls, retreats when its ELA rises, or melts entirely when its ELA rises above its summit [3]. In contrast to variations in glacier length or area, variations in ELA respond almost simultaneously to climate change. Reconstructions of ELAs in many regions using various methods, such as the accumulation area ratio (AAR),

*Corresponding author (email: happyabear@163.com) balance ratio (BR), altitude of lateral moraines (ALM), cirque floor altitude (CFA) and toe-to headwall altitude ratio (THAR) [3-10], have made great contributions to the study of past climatic and environmental changes. The sensitivity of ELA to climate change is a vital issue for predicting glacier behavior, and is the basis for quantitative reconstructions of past climate change using data on glacier variations [11,12]. Therefore, studies on ELA variations and their sensitivity to climate change are important for understanding correlations between glacier behavior and climate change.

During past several years, many studies have analyzed variations in mountain glacier areas and lengths, but few have focused on ELA variations. Urumqi Glacier No. 1 in the Tianshan Mountains has the longest ELA dataset about approximately 50 years [13-20]. Most other glaciers have datasets spanning shorter lengths of time of several years [16]. This limits the comparison of long-term ELAs' varia- 
tions and their sensitivities to climate change in different regions, which might explain spatial and temporal variations in glaciers in China. Much work has been carried out on Urumqi Glacier No.1 during past years [10-23]. However, few works has been done on the glacier ELA recently. In this study, we established a statistical model between the ELA of Urumqi Glacier No.1 and climatic factors (air temperature and precipitation) based on continuous observation data in the past 50 years, and then analyzed the sensitivity of the glacier ELA to climate change.

\section{Study area}

Figure 1 shows the location map of Urumqi Glacier No.1 in the Tianshan Mountains, China. There exists many deserts and Gobi Desert in Central Asia. The Tianshan Mountains are very important in the Xinjiang region for its climatic and environmental significance, where there exist many alpine glaciers. Urumqi River valley is located in the central Tianshan Mountains (Figure 1). There are 150 glaciers in this valley, with a total area of $45.99 \mathrm{~km}^{2}$. Glacier No. $1\left(43^{\circ} 05^{\prime} \mathrm{N}\right.$, $86^{\circ} 48^{\prime} \mathrm{E}$ ) is the largest glacier in the valley, which is composed of two branches, the east branch and west branch, with a total area of $1.73 \mathrm{~km}^{2}$, length of $2.41 \mathrm{~km}$, average snow line of $4075 \mathrm{~m}$ a.s.l. Based on the observation of Daxigou meteorological station, the mean annual air temperature is $-5.2^{\circ} \mathrm{C}$ in $3600 \mathrm{~m}$ a.s.l. of the glacial region, and $80 \%$ of precipitation occurred in warm season, from May to September $[13,14]$.
Glacier No.1 has been retreating since 1959 up to now, which showed an accelerated melting trend during recent 20 years. Mass balance change extent of Glacier No.1 is between many continental glaciers and temperate glaciers all over the world during the past 50 years, which is similar to that of mountain glaciers in central Asia. Based on the data of WGMS (World Glacier Monitoring Service, http://www. geo.uzh.ch/microsite/wgms/), the cumulative mass balance of 300 glaciers at various sites of the world during the past 40 years, varied from several meters to more than $30 \mathrm{~m}$ [23-29] (Figure 2). The cumulative mass balance of Glacier No. 1 is about $11 \mathrm{~m}$, which is of representative for mountain glaciers in central Asian region.

\section{Data and methods}

Mass balance is the basic and most important item for Urumqi Glacier No.1 observations since 1959, and there are more than 50 years data of field work observation. Mass balance observation began at 1959 . During the period [30,31] 1967-1979, the mass balance was interpolation data, and this part of the mass balance data was reconstructed through the correlationship between mass balance and meteorological data at the source region of Urumqi River during the period of 1958-1966 [23,29,32], mainly based on summer air temperature, which has been approbated and widely cited in previous research [19,20,29-32]. In other years of 1959- 2008, mass balance of Glacier No.1 was all observed in the field work. Mass balance observation is by measuring

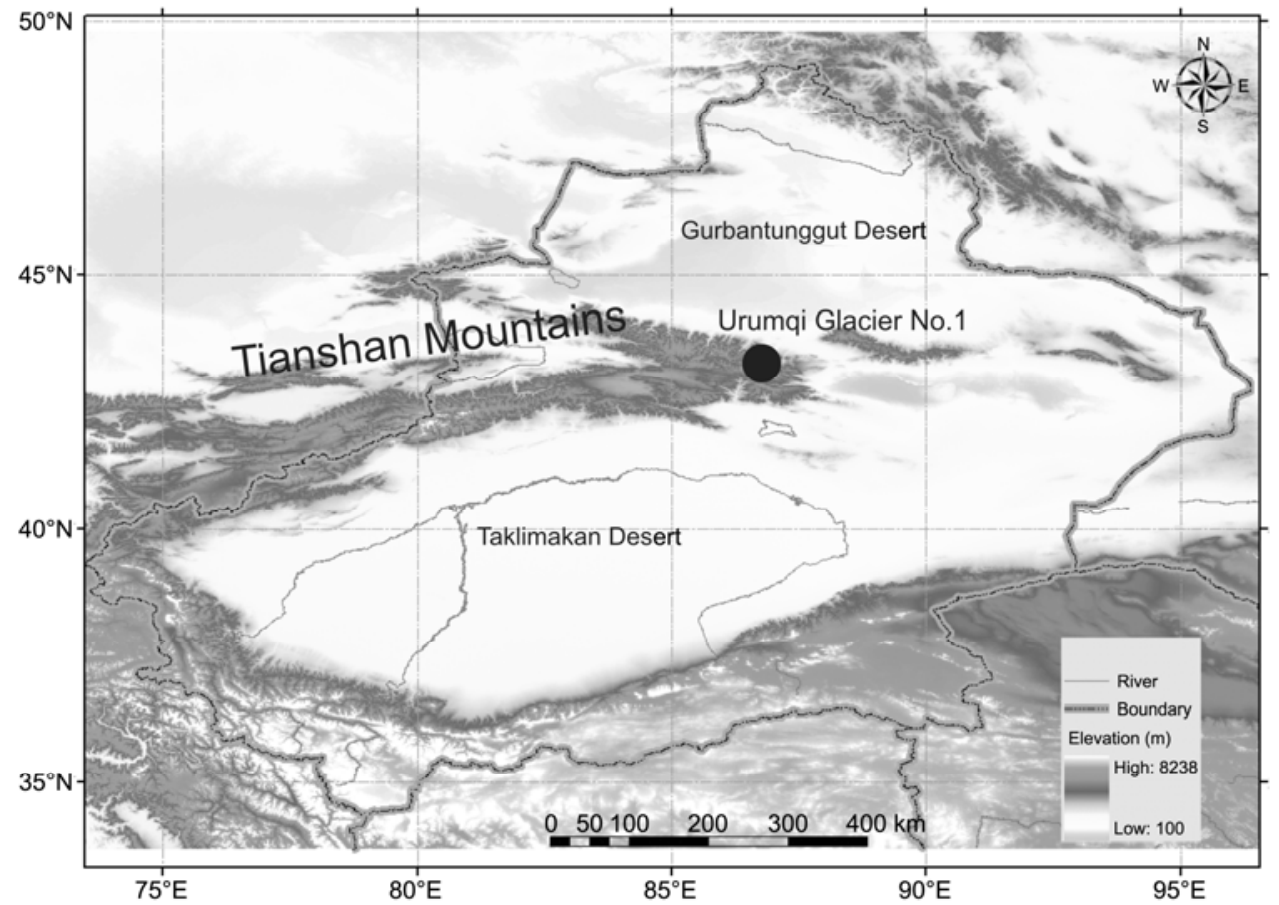

Figure 1 Location map of Urumqi Glacier No.1 in western China. 


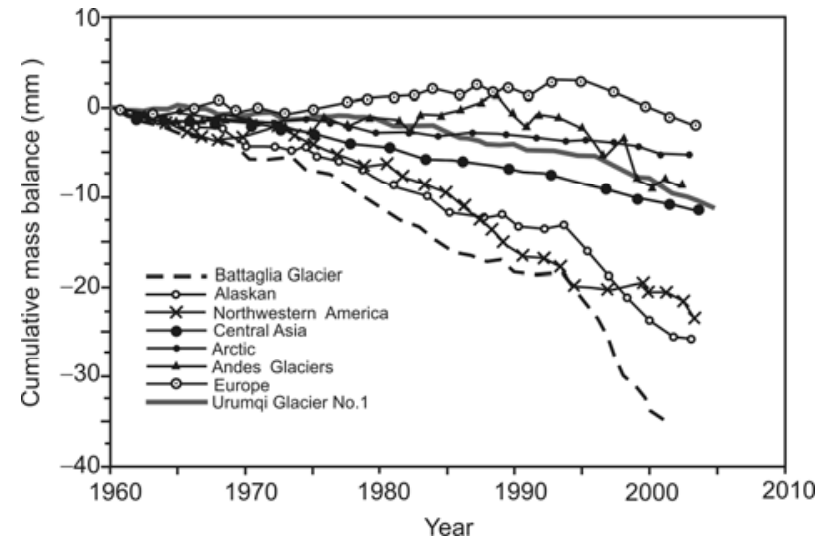

Figure 2 Comparison of mass balances between Urumqi Glacier No.1 and glaciers at various sites in the world.

stick on the glacier surface. The method has been introduced in detail in previous research [14-23]. The mass balance data of Urumqi Glacier No.1 in 1959-2008 is shown here in Table 1.
The mass balance of the single point in Glacier No.1 was obtained by

$$
b_{\mathrm{n}}=b_{\mathrm{i}}+b_{\mathrm{s}}+b_{\mathrm{si}},
$$

among, $b_{\mathrm{n}}, b_{\mathrm{i}}, b_{\mathrm{s}}$ and $b_{\mathrm{si}}$ are the mass balance of single point, glacier ice, snow and affiliated ice, respectively. Mass balance of the whole glacier [31] is calculated by

$$
b_{\mathrm{n}}=\Sigma b_{\mathrm{j}} S_{\mathrm{j}} \text {. }
$$

We determined the ELA of Urumqi Glacier No.1 using the altitudinal profile of the annual mass balance by measuring sticks, and the altitude where annual mass balance was zero was defined as ELA. The observed ELAs in different periods are presented in Table 1. The highest observed ELA of Glacier No.1 occurred in the balance year (from the previous September 1 to the next August 31) 2007/2008, reaching $4168 \mathrm{~m}$ a.s.1., close to the glacier summit. This implies that the whole glacier was ablating in that balance year (Figure 3). Observation showed that, the mass balance is $-931.92 \mathrm{~mm}$ in this year, showing very

Table 1 ELA, AAR and mass balance of Urumqi Glacier No.1 during the past 50 years

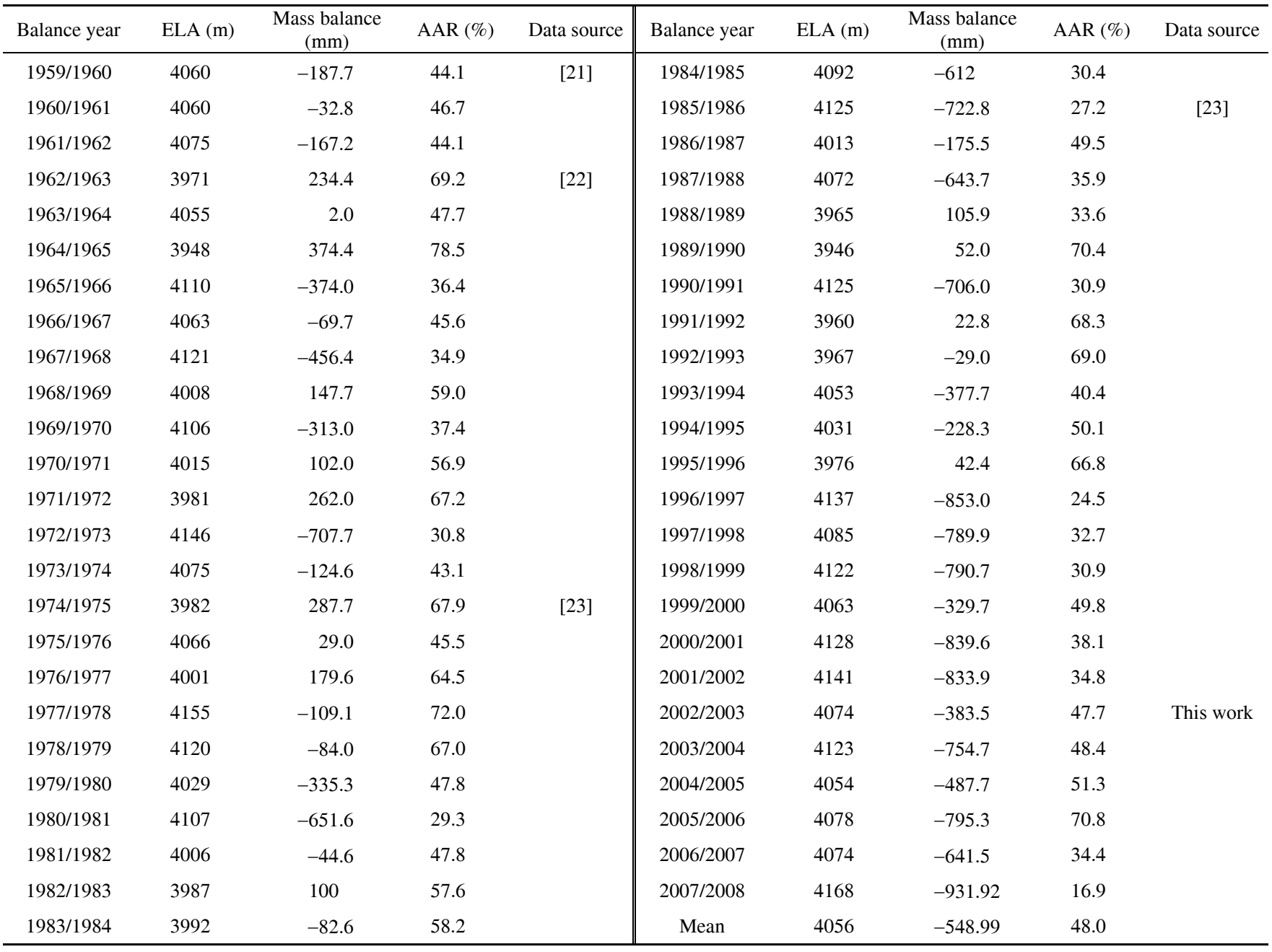



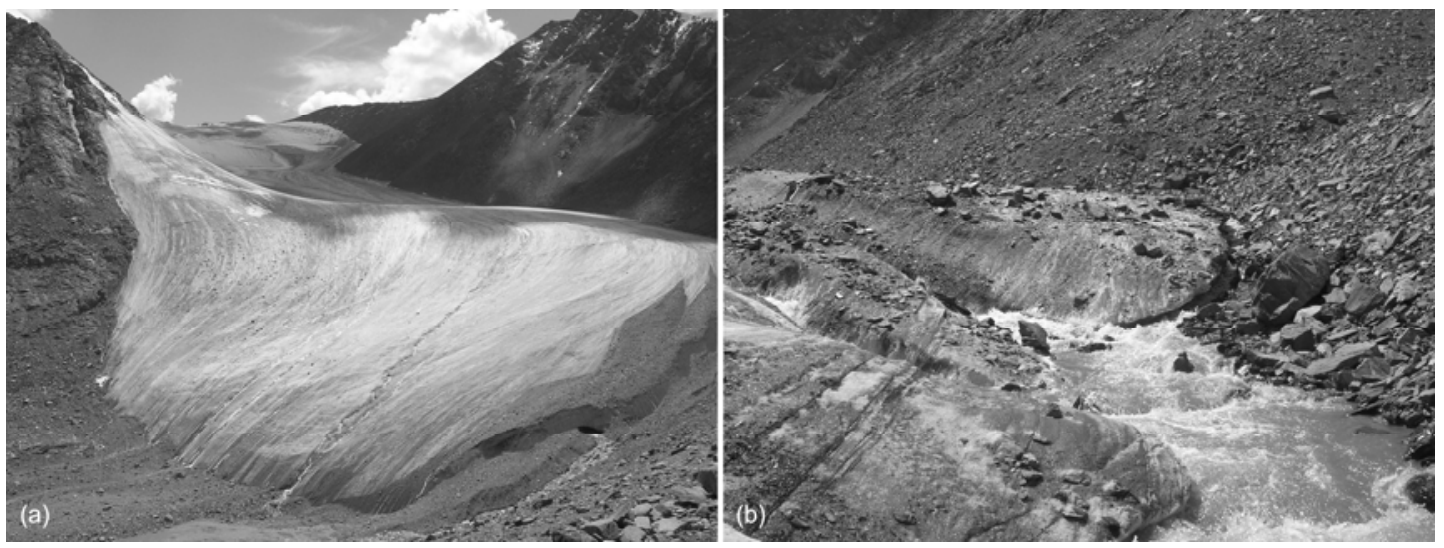

Figure 3 Strong melting of Urumqi Glacier No.1 in summer 2008, snow line of eastern branch (a), and melting water at the bottom of western branch (b).

strong melting of snow and ice. Generally, Glacier No.1 ELA showed an increasing trend over the past 50 years, especially during recent 20 years (Figure 4 ).

Statistical models correlating ELA and air temperature and precipitation $[28,29]$ using data from nearby meteorological stations are effective for reconstructing past correlation between ELA and climate factors and investigating ELA sensitivity to climate change [3]. We will use these models here to investigate the state of the ELA of Urumqi Glacier No.1.

Meteorological datasets, air temperature and precipitation, with a time period of 1959-2008, are obtained from Daxigou Meteorological Station, which is located at $3600 \mathrm{~m}$ a.s.l. in the glacial region, only $4 \mathrm{~km}$ away from Urumqi Glacier No.1. The data is well coincident with that of three hydro- meteorological stations at the Urumqi River source, which thus could reflect the climate change of the Urumqi River source very well [29-32].

\section{Results and discussion}

ELA is the boundary of accumulation zone and ablation zone on the glacier, which is closely correlated with climatic factors and the glacier surface geomorphology. ELA is one of the important glacier parameters for climate change. On the ELA, the annual mass balance was zero. ELA is also well correlated with snow line on the mountain glaciers, and its change has been paid widely attention during recent years. The Urumqi glacier No.1 ELA varied between 3946$4168 \mathrm{~m}$ a.s.l. during the past 50 years, with a mean value of $4056 \mathrm{~m}$ a.s.l. The ELA in positive mass balance year was $92 \mathrm{~m}$ lower than that of negative mass balance year. ELA in 36 negative mass balance years varied between 3967-4168 $\mathrm{m}$ a.s.l., with a mean of $4082 \mathrm{~m}$ a.s.l.; while ELA in 14 positive mass balance years varied between 3946-4066 m a.s.l., with a mean value of $3990 \mathrm{~m}$ a.s.l.. We find that, the ELA shows a very similar variation trend with the air temperature of Daxigou Meteorological Station at Urumqi River source

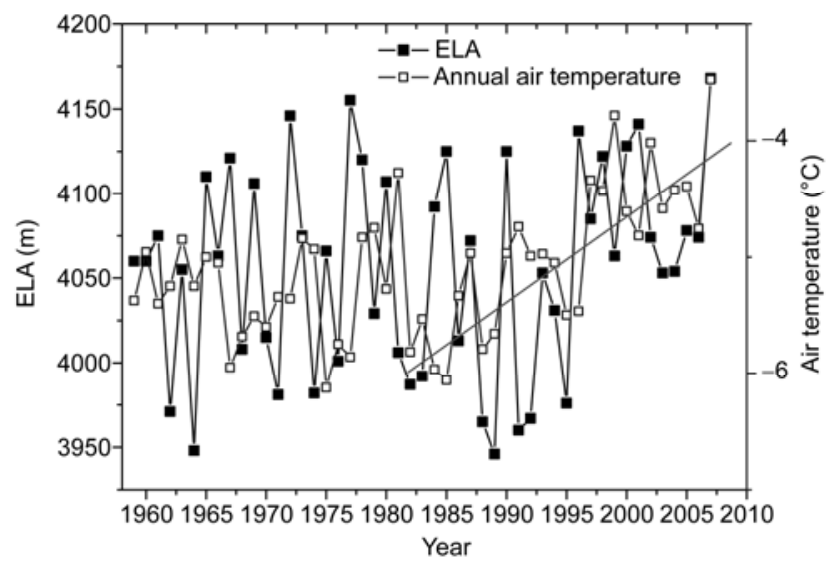

Figure 4 Variation of ELA and annual air temperature during 1959-2008, and straight line is the regression for change trend of the glacier ELA since 1985.

(Figure 4). The glacier ELA has increased significantly since 1996. Previous research has indicated that ELA was positive correlation with air temperature, but negative correlation with precipitation [11-14]. In this study, we analyses the correlation between Urumqi Glacier No.1 ELA and air temperature and precipitation during the past 50 years, demonstrating the coincidence between ELA and air temperature variation. The ascending trend of the glacier ELA is mainly controlled by the increase of contemporaneous air temperature, especially the air temperature showing accelerated increasing trend since 1985 [13,20] (Figure 4), indicating the strong influence of air temperature on the glacier ELA, mass balance and runoff change during the past 50 years [33].

Figure 4 also presents that there were two stages for the glacier ELA variation. During the period 1959-1985, ELA showed a relatively stable variation. However, during 19852008, especially since 1995, the glacier ELA showed an obvious increasing trend, reaching its highest altitude in 2008 at $4168 \mathrm{~m}$ a.s.l., close to the glacier summit. During the whole period 1959-2008, the glacier ELA showed a 
general increasing trend, ascending about $108 \mathrm{~m}$. Figure 5 indicates the correlationship between the glacier ELA and warm season air temperature (May-August) and annual mean temperature during 1959-2008. We then obtained the correlationship model between the glacier ELA and summer air temperature $\left(T_{\mathrm{s}}\right)$ and annual mean temperature $(T)$ :

$$
\begin{aligned}
& \mathrm{ELA}=3921.8+44.2 T_{\mathrm{s}}, \\
& \mathrm{ELA}=4209.1+30.38 T .
\end{aligned}
$$

Results showed that ELA has a very good linear correlation with air temperature. With the increase of air temperature, the ELA shows an ascending trend. Moreover, the summer air temperature (May, June, July, August) seems more important to ELA change (Figure 5), showing high correlation coefficient $(R=0.6331)$. The slope of the regression line of the correlation between ELA and summer air temperature is larger, implying that the ELA will ascend more quickly when summer air temperature increase. This result also reflects the significant sensitivity of the glacier ELA to summer air temperature change during the period 1959-2008.
Besides air temperature, the glacier ELA was also influenced by precipitation in the glacial region. Research at other sites has indicated that, when the precipitation increased, the snow line and ELA of the glacier would descends, showing negative correlation $[2,3,16]$. Figure 6 shows the correlation between Urumqi Glacier No.1 ELA and annual precipitation during the period 1959-2008, and increasing trend of precipitation at Urumqi River source. We can infer that, as precipitation increase could cause the decline of ELA, the ascending trend of the glacier ELA was caused by air temperature rising. However, we cannot ignore the effect of precipitation to ELA change. We then established the correlationship between ELA and precipitation:

$$
\mathrm{ELA}=4109.2-0.1221 P .
$$

Table 2 shows correlations between the glacier ELA and air temperature and precipitation. Results showed that ELA has good correlation with summer air temperature (May, June, July, and August) and relative good correlation with annual precipitation. Eqs. (3) and (5) indicate that the influence of warm season air temperature on ELA is more important than that of annual precipitation. This is verified
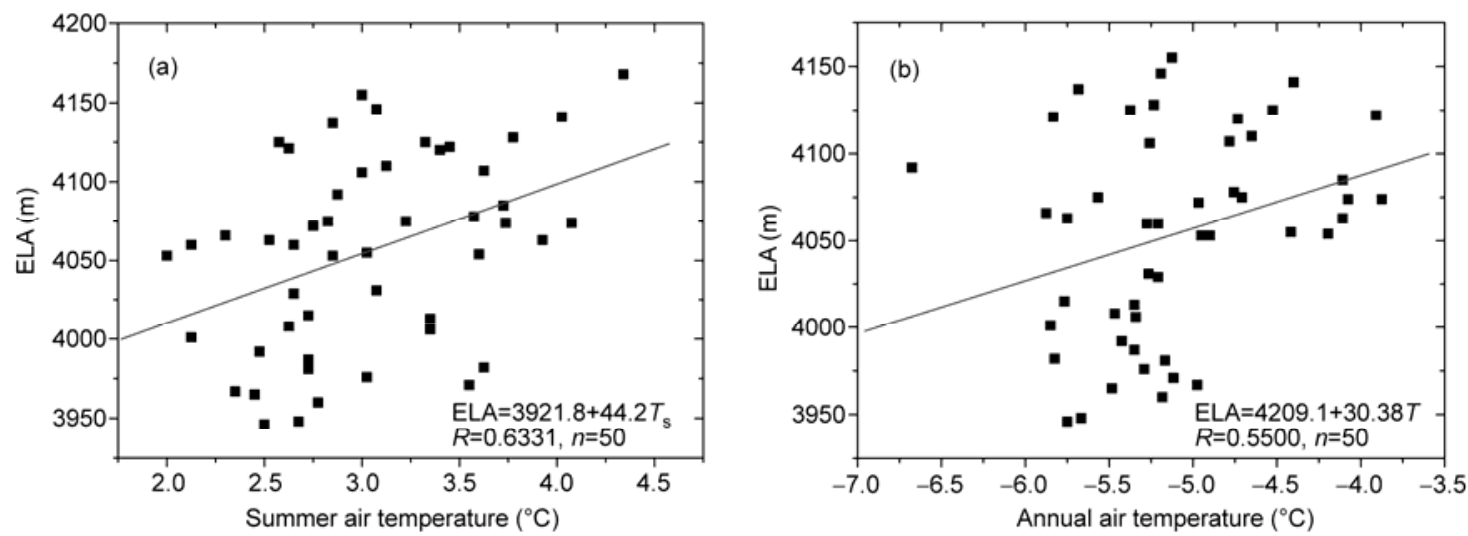

Figure 5 Correlation between Urumqi Glacier No.1 ELA and summer air temperature (a); and annual air temperature (b) during 1959-2008, significant at the 0.001 level.
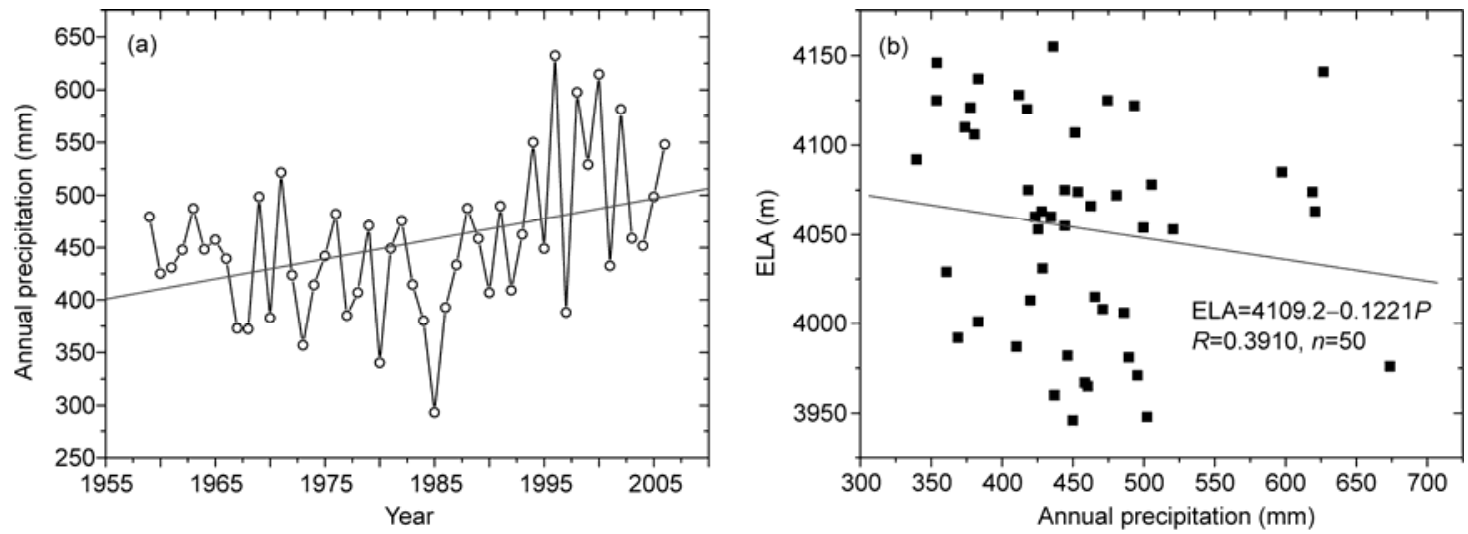

Figure 6 Variation of annual precipitation during 1959-2008 (a), correlation between Urumqi Glacier No.1 ELA and annual precipitation (b), significant at the 0.01 level. 
Table 2 Correlation coefficients between ELA and air temperatures, and precipitations at Daxigou meteorological station in different periods of the year ${ }^{\text {a) }}$

\begin{tabular}{lcc}
\hline & Air temperature & Precipitation \\
\hline September & $0.460^{*}$ & 0.475 \\
October & 0.348 & -0.023 \\
November & 0.343 & 0.004 \\
December & 0.352 & 0.031 \\
January & 0.527 & 0.032 \\
February & 0.629 & -0.243 \\
March & 0.377 & -0.147 \\
April & 0.584 & 0.120 \\
May & 0.312 & 0.268 \\
June & $0.805^{*}$ & -0.415 \\
July & $0.856^{*}$ & 0.1672 \\
August & $0.573^{*}$ & 0.423 \\
Balance year & $0.550^{*}$ & 0.391 \\
May-August & $0.633^{*}$ & 0.103 \\
\hline
\end{tabular}

a) * Significant at the 0.001 level.

by the fact that the correlation coefficients between ELA and warm season air temperature are much higher than those between ELA and annual precipitation (Table 2). However, in this work we need to consider both air temperature and precipitation factors, and establish a model to find out the sensitivity of the glacier ELA to climate change.

To investigate the sensitivity of the Urumqi Glacier No.1 ELA to climate change and reconstruct the past ELA and climate model, using a function of Linest, we established a correlation between ELA, summer air temperature $\left(T_{\mathrm{s}}\right)$ and annual Precipitation $(P)$ at the glacial region of Urumqi River source in the period 1959-2008:

$\mathrm{ELA}=3988.1+61.6524 T_{\mathrm{s}}-0.2601 P,(R=0.8268, n=50)$.

The variance test for the regression formula indicated that the significance was at 0.001 level. We investigated the sensitivities of the Urumqi Glacier No.1 to variabilities in warm season air temperature and annual precipitation using eq. (6). The results showed that the glacier ELA ascends (descends) $61.7 \mathrm{~m}$ when warm season air temperature increases (decreases) by $1^{\circ} \mathrm{C}$, and ascends (descends) $13.1 \mathrm{~m}$ when cold season precipitation decreases (increases) by $10 \%$. If future climate is similar to that in the past 50 years (slope is $0.019^{\circ} \mathrm{C} / \mathrm{a}$ ), the ELA of Urumqi Glacier No.1 will still ascend with a speed of $2.16 \mathrm{~m} / \mathrm{a}$. However, If future climate is similar to that in the period 2000-2008 (slope is $\left.0.059^{\circ} \mathrm{C} / \mathrm{a}\right)$, the ELA will still ascend with a speed of 6.5 $\mathrm{m} / \mathrm{a}$ before it is stable.

Much research has been carried out on the glacier ELA in different regions of the world. Recent research in the Qiyi Glacier in the Qilian Mountains has indicated that the glacier ELA ascends (descends) $172 \mathrm{~m}$ when warm season air temperature increases (decreases) by $1{ }^{\circ} \mathrm{C}$, and ascends (descends) $62 \mathrm{~m}$ when cold season precipitation decreases (increases) by $10 \%$. In the period 1958-2008, the glacier ELA showed a general increasing trend, ascending $230 \mathrm{~m}$ and reaching its highest altitude in 2006 at $5131 \mathrm{~m}$ a.s.l., close to the glacier summit [3]. After analyzing observation data from more than 70 monitoring glaciers around the world, Ohmura et al. [27] also found that ELA sensitivities to variability in air temperature and precipitation were linear. Recently, a study on the sensitivity of ice caps in Severnaya Zemlya in the high Arctic to climate change showed that perturbations in air temperature result in considerable changes in ELA, ranging from 175 to $241 \mathrm{~m} /{ }^{\circ} \mathrm{C}$, and changes in precipitation by $10 \%$ result in ELA changes by 50-70 m [25]. At Solheimajokull, a valley glacier outlet of the Myrdalsjokull in Iceland, a $1{ }^{\circ} \mathrm{C}$ air temperature change caused an ELA shift of $160 \mathrm{~m}$, and a $10 \%$ change in precipitation resulted in a $22 \mathrm{~m}$ shift in ELA [26]. The ELA sensitivity of glaciers in the French Alps to air temperature alone was $125 \mathrm{~m} /{ }^{\circ} \mathrm{C}$, or even $160 \mathrm{~m} /{ }^{\circ} \mathrm{C}$ if concurrent long wave radiation change was taken into account [28]. For glaciers in the humid lower tropics, the change in ELAs caused by a $1{ }^{\circ} \mathrm{C}$ change in air temperature alone was $182 \mathrm{~m} \mathrm{[28].} \mathrm{These}$ studies show that ELAs sensitivities to climate change in the same region or in different regions vary. This is possibly one of the major external causes for differing responses of glacier terminuses in the same or different regions to the same climate change, and the internal causes may be related to glaciers' dimension and dynamics [3].

Some work has been carried out on the glacier mass balance, ELA and climatic change at Urumqi Glacier No.1 during past 20 years by Chinese researchers. Zhang et al. [22] has constructed the function between the Glacier No.1 ELA and precipitation during the period 1962-1996. Wang et al. [12,19] showed that ELAs of its east and west branches of Glacier No.1 changed differently when the climate change in the period 1959-1999. Liu et al. [18] has discussed the correlation between ELA and summer air temperature and annual precipitation. The previous work is very important for providing the data and discussion of this work. However, these works were carried out many years ago. In this study, we have collected more data of 50 years, and established the improved model between ELA, summer air temperature $\left(T_{\mathrm{s}}\right)$ and annual Precipitation $(P)$ at the glacial region of Urumqi River source in 1959-2008.

We also analyzed the variation of AAR (accumulation area ratio) of Urumqi Glacier No.1 during the past 50 years, based on the glacier mass balance (Table 1). AAR could reflect ratio between the accumulation zone and ablation zone of the glacier. During the period 1959-2008, the AAR of Glacier No.1 showed an obvious decreasing trend (Figure 7 ). The AAR varied between $16.9 \%-78.5 \%$, with an average value of $48.0 \%$. Thus we can infer that, the glacier ELA is mainly influenced by global warming, which then cause 


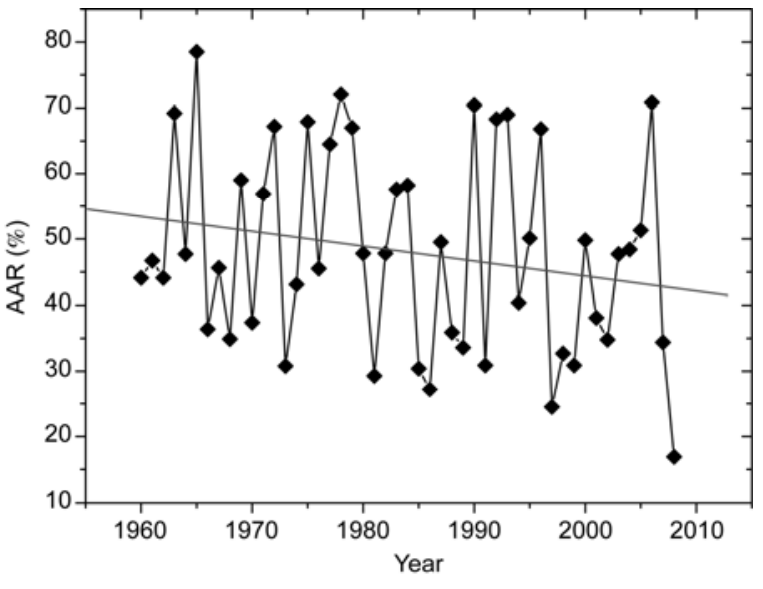

Figure 7 AAR variation of Urumqi Glacier No.1 over the past 50 years.

the AAR decrease during the past 50 years. This may cause more and more ablation of mountain glaciers under global warming in future.

\section{Conclusions}

Equilibrium line altitude (ELA) of mountain glaciers is one of the important parameters indicating climate change. Based on observations of the equilibrium line altitude of Urumqi Glacier No.1 in Tianshan Mountains, we established a statistical model between ELA and its major influencing factors, warm season air temperature (air temperature averages for May, June, July and August) and annual precipitation. Warm season air temperature was the leading climatic factor influencing ELA variations. Based on the model, we also analyzed the sensitivity of the glacier ELA to climate change. The glacier ELA ascends (descends) $61.7 \mathrm{~m}$ when warm season air temperature increases (decreases) by $1^{\circ} \mathrm{C}$, and ascends (descends) $13.1 \mathrm{~m}$ when cold season precipitation decreases (increases) by 10\%. In the period 19592008, the glacier ELA showed a general increasing trend, ascending $108 \mathrm{~m}$ and reaching its highest altitude in 2008 at $4168 \mathrm{~m}$ a.s.l., close to the glacier summit. This implies that the whole glacier was ablating in that balance year.

If future climate is similar to that in the past 50 years (slope is $0.019^{\circ} \mathrm{C} / \mathrm{a}$ ), the ELA of Urumqi Glacier No.1 will still ascend with a speed of $2.16 \mathrm{~m} / \mathrm{a}$. However, If future climate is similar to that in the period 2000-2008 (slope is $\left.0.059^{\circ} \mathrm{C} / \mathrm{a}\right)$, the ELA will still ascend with a speed of 6.5 $\mathrm{m} / \mathrm{a}$ before it is stable. As a result of the ELA change, the accumulation area ratio (AAR) of accumulation zone showed a decreasing trend during the past 50 years, which might cause more and more ablation of mountain glaciers under global warming in future.

The authors would like to thank three anonymous reviewers for their constructive suggestions, and thank Prof. Chen Rensheng for his suggestions on mathematic model. This work was supported by the National Natural Science Foundation of China (41121001 and 41171053) and the China Postdoctoral Science Foundation (2012M512049).

1 Haeberli W, Barry R, Cihlar J. Glacier monitoring within the Global Climate Observing System. Ann Glaciol, 2000, 31: 241-246

2 Wang $\mathrm{N} \mathrm{L}$, Yao T D, Pu J C. Climate sensitivity of the Xiao Dongkemadi Glacier in the Tanggula Pass. Cryosphere, 1996, 2: 63-66

3 Wang N L, He J Q, Pu J C, et al. Variations in equilibrium line altitude of the Qiyi Glacier, Qilian Mountains, over the past 50 years. Chin Sci Bull, 2010, 55: 3107-3115

4 Poter S C. Equilibrium-line altitudes of late Quaternary glaciers in Southern Alps, New Zealand. Quat Res, 1975, 5: 27-47

5 Nesje A. Younger Dryas and Holocene glacier fluctuations and equilibrium-line altitude variations in the Jostedalsbre region, western Norway. Clim Dyn, 1992, 6: 221-227

6 Rodbell D T. Late Pleistocene equilibrium-line reconstructions in the northern Peruvian Andes. Boreas, 1992, 21: 43-52

7 Ballantyne C. The Loch Lomond Readvance on the Isle of Mull, Scotland: Glacier reconstruction and palaoclimatic implications. J Quat Sci, 2002, 17: 759-771

8 Kovanen D J, Slaymaker O. Fluctuations of the Deming Glacier and theoretical equilibrium line altitudes during the Late Pleistocene and Early Holocene on Mount Baker, Washington, USA. Boreas, 2005, 34: $157-175$

9 Kayastha R B, Harrison S P. Changes of the equilibrium-line altitude since the Little Ice Age in the Nepalese Himalaya. Ann Glaciol, 2008, 48: 93-99

10 Zhang $\mathrm{Z} \mathrm{S}$. Change of snowline at the source area of the Urumqi River, Tianshan Mountains (in Chinese). J Glaciol Geocryol, 1981, 3(Suppl): 106-112

11 Klok E J, Oerlemans J. Climate reconstructions derived from global glacier length records. Arct Antarct Alp Res, 2004, 36: 575-583

12 Wang $\mathrm{N} \mathrm{L}$, Liu S Y. Summer temperature rise quantified from the change of the Glacier No.1 at the source of Urumqi River in the 20th century (in Chinese). J Glaciol Geocryol, 1997, 19: 207-213

13 Li Z Q, Han T D, Jing Z F, et al. A summary of 40-year observed variation facts of climate and glacier No.1 at headwater of Urumqi River, Tianshan, China (in Chinese). J Glaciol Geocryol, 2003, 25: 117-123

14 Liu S Y, Ding Y J, Wang N L, et al. Mass balance sensitivity to climate change of the Glacier No. 1 at the Urumqi River head, Tianshan Mts. (in Chinese). J Glaciol Geocryol, 1998, 20: 9-13

15 Yao T D. The relationship between glacial mass balance equilibrium line and climate (in Chinese). J Glaciol Geocryol, 1987, 9: 290-300

16 Ju Y H, Liu G N, Zhang X Y, et al. High mountain glaciers' ELA and climate (in Chinese). Prog Geogr, 2004, 23: 43-49

17 Yang H A, Li Z Q, Ye B S, et al. Study on mass balance and process of Glacier No.1 at the headwaters of the Urumqi River in the past 44 years (in Chinese). Arid Land Geogr, 2005, 28: 76-80

18 Liu C H, Xie Z C, Wang C Z. A Research on the mass balance processes of Glacier No.1 at the headwaters of the Urumqi River, Tianshan Mountains (in Chinese). J Glaciol Geocryol, 1997, 19: 17-24

19 Wang N L, Zhou Y B. A new approach of analyzing the influence of climate change on the ELA: Application of grey theory in glaciology (in Chinese). In: Proceedings of the Fifth Chinese Conference on Glaciology and Geocryology, Vol.1. Lanzhou: Gansu Culture Press, 1996. 205-212

20 Ye B, Yang D, Jiao K, et al. The Urumqi River source Glacier No. 1, Tianshan, China: Changes over the past 45 years. Geophys Res Lett, 2005, 32: L21504

21 Xie Z C, Ding L F, Liu C H, Mass balance at the steady state equilibrium line altitude and its application (in Chinese). J Glaciol Geocryol, 1996, 18: 1-9

22 Zhang J H, Wang X J, Li J. Study on relationship between mass balance change of Glacier No.1 at the headwater of Urumqi River, Tianshan and climate. J Glaciol Geocryol, 1984, 6: 25-36

23 Tianshan Glaciological Station. Annual Report of Tianshan Glacio- 
logical Station, Vol. 1-18. Lanzhou: Tianshan Glaciological Station Press. 1980-2008

24 Kuhn M. The response of the equilibrium line altitude to climate fluctuations: Theory and observations. In: Oerlemans J, ed. Glacier Fluctuations and Climate Change. Dordrecht: Kluwer Academic Publishers, 1989. 407-417

25 Bassford R P, Siegert M J, Dowdeswell J A. Quantifying the mass balance of ice caps on Severnaya Zemlya, Russian High Arctic III: Sensitivity of ice caps in Severnaya Zemlya to future climate change. Arct Antarct Alp Res, 2006, 38: 21-33

26 Mackintosh A N, Dugmore A J, Hubbard A L. Holocene climatic changes in Iceland: Evidence from modeling glacier length fluctuations at Solheimajokull. Quat Int, 2002, 91: 39-52

27 Ohmura A, Kasser P, Funk M. Climate at the equilibrium line of glaciers. J Glaciol, 1992, 38: 397-411

28 Dyurgerov M B. Mountain glaciers at the end of the twentieth century: Global analysis in relation to climate and water cycle. Polar Geogr,
2001, 25: 241-336

29 Li Z Q, Shen Y P, Wang F T, et al. Response of glacier melting to climate change-Take Urumqi Glacier No.1 as an example (in Chinese). J Glaciol Geocryol, 2007, 29: 333-342

30 Jiao K Q, Ye B S, Han T D, et al. Response of runoff to climate change in the Glacier No.1 at the headwater of Urumqi River, Tianshan Mountains during 1980-2006 (in Chinese). J Glaciol Geocryol, 2011, 33: 606-611

31 Han T D, Liu S Y, Ding Y J, et al. Characteristics of mass balance of Glacier No.1 at the headwaters of Urumqi River, Tianshan Mountains (in Chinese). Adv Earth Sci, 2005, 20: 298-303

32 Zhang J H. Mass balance studies on the Glacier No.1 of Urumqi River in Tianshan Mountains (in Chinese). J Glaciol Geocryol, 1981, 3: $32-40$

33 Li X Y, Ding Y J, Ye B S, et al. Changes in physical features of Glacier No. 1 of the Tianshan Mountains in response to climate change. Chin Sci Bull, 2011, 56: 2820-2827

Open Access This article is distributed under the terms of the Creative Commons Attribution License which permits any use, distribution, and reproduction in any medium, provided the original author(s) and source are credited. 